\title{
The genesis of kimberlite: geochemical constraints
}

\author{
D. G. Pearson ${ }^{1}$, G.M. Nowell ${ }^{1}$, B.A. Kjarsgaard ${ }^{2}$, D.P. Dowall ${ }^{1}$ \\ 1: Dept. Earth Sciences, Durham University, Durham, DH1 3LE UK. \\ 2: Geological Survey of Canada, Ottawa, Canada
}

\section{Introduction}

Deciphering the geochemical signatures of kimberlites, with the aim of constraining their source regions, has long been a "holy grail" in kimberlite studies. The complex, hybrid nature of kimberlites has contributed to the broad spectrum of petrogenetic models available that range from ultra-deep asthenospheric melts to more classical models that involve melting of the continental lithospheric mantle. Recently, models that involve both asthernospheric and lithospheric source components have evolved, with the lithosphere either acting as a "contaminant” e.g., Nowell et al. (2004) or as the sink for asthenosphere-derived metasomatic agents that later re-melt to yield kimberlite (le Roex et al., 2003; Becker and le Roex, 2006). These latter models show that the incompatible trace element patterns of S. African kimberlites can be generated by small degrees of melting (0.4 to $1.5 \%)$ of a metasomatised garnet lherzolite source that has been enriched by a melt already possessesing kimberlite-like trace element characteristics. These, along with all other models, are non-unique and blur the issue of the ultimate source of kimberlitic melts that move through the mantle and appear to be important in diamond genesis (Schrauder \& Navon, 1996; Klein benDavid et al., this volume).

While the effects of both crustal and lithospheric mantle contamination have been previously recognized, only recently have their effects on key geochemical signatures been appreciated (le Roex et al. 2003). New major and trace element data for fresh, hypabyssal kimberlites from the Lac de Gras (LDG) region (N. Canada) allow crustal interaction to be quantitatively addressed. These data, along with others compiled from the literature show clearly that primitive kimberlite melts are alkali-poor, $\mathrm{MgO}$ and water-rich with $\mathrm{CO}_{2}$ (Kjarsgaard et al., this volume). When recently determined, more robust estimates of primary kimberlite melt compositions are compared with experimental data most experimental liquids are poor overall matches for kimberlite compositions. The best match appears to be a hydrous harzburgitic source containing either carbonate and/or subducted oceanic crust component, at transition zone depths (Kjarsgaard et al., this volume). In this contribution we apply trace element and multi-isotopic (Sr-Nd-Hf-Os) constraints to archetypal (Group I) kimberlites to test such a model and place further constraints on kimberlite origin.

\section{Isotopic characteristics of kimberlites}

When kimberlites from North America and S. Africa are filtered for the effects of crustal contamination, their Sr-Nd isotope systematics fall within the array of data defined by OIB. Any Group I kimberlites with ${ }^{87} \mathrm{Sr} /{ }^{86} \mathrm{Sri}$ values falling outside the OIB field can be readily reconciled with crustal addition. Moreover, $\mathrm{Sr}$ isotope analysis of perovskites reveal that the measured Sr isotope compositions of kimberlite bulk rocks are probably all affected by crustal input to a greater (Paton et al., 2007) or lesser (Malarkey et al., this volume) extent. Accounting for these effects, the Sr$\mathrm{Nd}$ isotope systematics of kimberlites can equally be explained by a convecting mantle origin or via recent enrichment of lithosphere by melts from the convecting mantle. Hf isotopes reveal a different perspective. While kimberlite Nd-Hf isotope systematics scatter around values characteristic of OIB, South African kimberlites and their megacrysts fall consistently below the mantle Nd-Hf "array", with most samples falling outside of the OIB field, having anomalously low $\Delta \varepsilon$ Hf values (Nowell et al., 2004; Fig. 1).

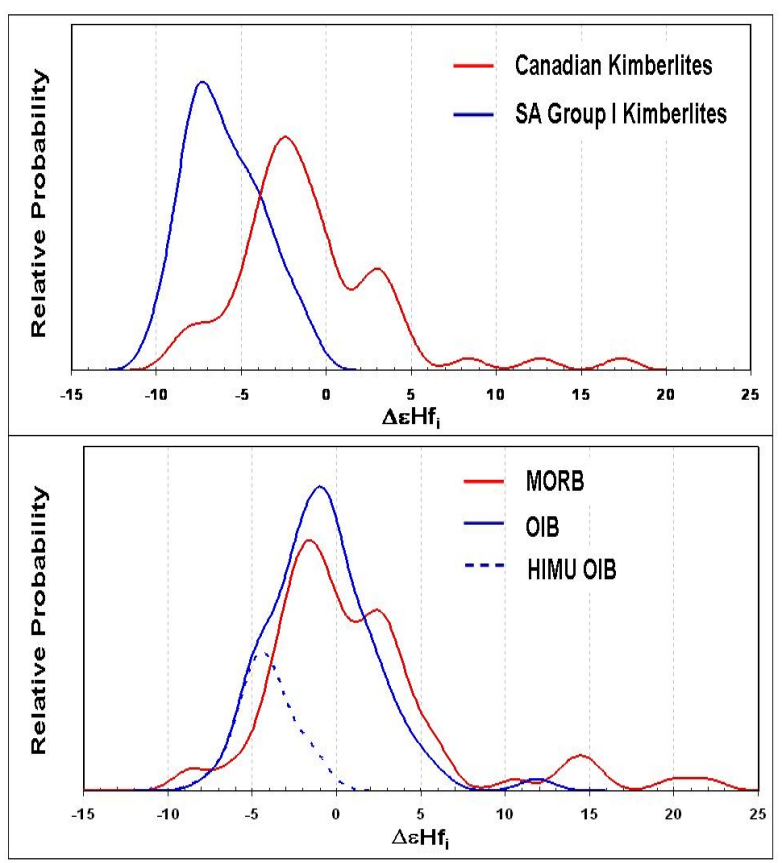

Figure 1. Probability density plot for $\Delta \varepsilon \mathrm{Hf}_{\mathrm{i}}$ for $\mathrm{S}$. African and Canadian kimberlites (upper panel) and basalts from the ocean basins (lower panel).

Minimally contaminated LDG kimberlites have a subpopulation falling below the mantle $\mathrm{Nd}-\mathrm{Hf}$ isotope array, but many overlap of the OIB field (Fig. 1). Only OIB with "HIMU" characteristics have $\Delta \varepsilon \mathrm{Hf}$ values approaching the low values seen in some kimberlites. For the LDG kimberlites a sub-population also extend 
well above the mantle array, to radiogenic Hf but with $\mathrm{Nd}$ isotopic compositions that are close to "Bulk Earth". These radiogenic Hf isotope compositions are difficult to achieve via contamination with lithospheric mantle.

New Os isotope data for Group I Kaapvaal and Slave kimberlites show significant heterogeneity that spans the range of OIB and extends to significantly lower values $\left({ }^{187} \mathrm{Os} /{ }^{188} \mathrm{Os}\right.$ as low as 0.1147 ; Fig. 2).

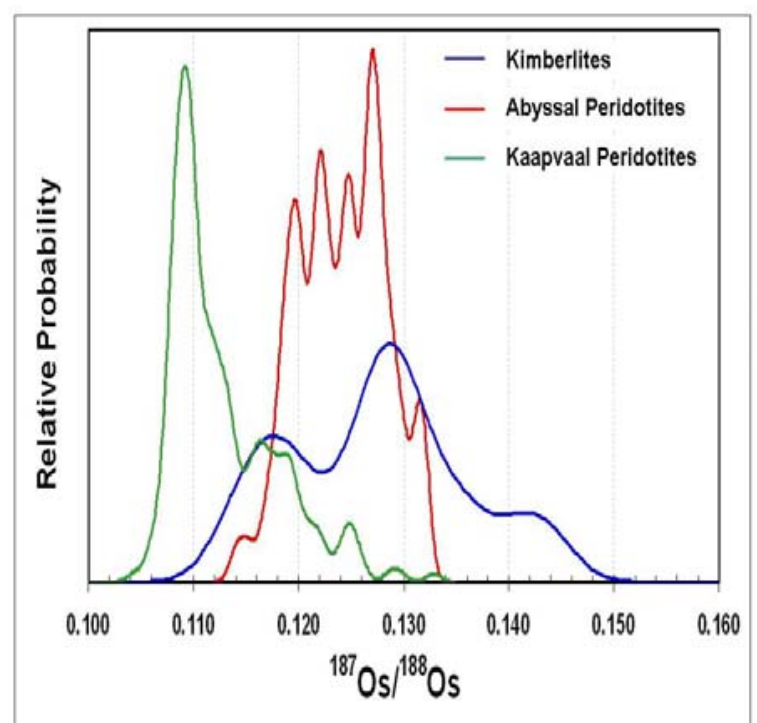

Figure 2. Probability density plot for ${ }^{187} \mathrm{Os} /{ }^{188} \mathrm{Os}$ isotope ratio in kimberlites abyssal peridotites and Kaapvaal peridotites. Kaapvaal data taken from compilations by Carlson et al. (2005) and Pearson \& Wittig (in press). Abyssal data from compilation in Pearson et al. (2007).

While some of these lower values are almost certainly influenced by the assimilation of lithospheric peridotite it is notable that none of the kimberlite values fall outside of the range reported for abyssal peridotites (Fig. 2). Os concentrations vary widely, from $\sim 150 \mathrm{ppt}$ to 2500 ppt. The low Os kimberlites have the most radiogenic ${ }^{187} \mathrm{Os} /{ }^{188} \mathrm{Os}$ (up to 0.322 ) and it is difficult to rule out the effects of minor assimilation of Archean crust in generating such ratios. The effects of crustal contamination in these rocks is strongly supported by their much higher $\mathrm{Al}_{2} \mathrm{O}_{3}$ contents (up to $4.3 \mathrm{wt} \%$ ), elevated $\mathrm{Na}_{2} \mathrm{O}$ and high $\mathrm{Yb}$ (up to $0.8 \mathrm{ppm}$ ) compared with minimally contaminated samples. Such radiogenic compositions are atypical and ${ }^{187} \mathrm{Os} /{ }^{188}$ Os values are mostly between 0.15 and 0.115 , with a primary mode of $\sim 0.130$, close to some estimates of "Primitive Mantle" with a secondary mode around 0.115 , close to the lower end of the abyssal peridotite distribution (Fig. 2). Analysis of a S. African Group II kimberlite demonstrates that removal of olivine xenocrysts has the marked effect of increasing the ${ }^{187} \mathrm{Os} /{ }^{188}$ Os ratio of the resulting xenocryst-poor kimberlite. This leads to the expectation that Os isotope compositions should correlate with Os concentrations in the unradiogenic samples due to lithosphere addition. Although kimberlites with the highest Os contents tend to have the lowest ${ }^{187} \mathrm{Os} /{ }^{188}$ Os the correlation between Os isotope ratio and concentration is poor for Slave and $\mathrm{S}$. African kimberlites. Other indicators of possible olivine addition such as bulk rock $\mathrm{Ni}$ and $\mathrm{MgO}$ also show poor overall correlations with Os isotope composition and suggest that other factors also influence these unradiogenic os isotopic compositions.

\section{Discussion}

When trying to reconcile the isotope compositions of kimberlites with their possible source regions the different properties of each isotopic tracer play a key role. For instance, in Os-rich melts, Os isotopic compositions should be dominated by the depleted, peridotitic component, with less influence from any enriched vein or recycled components. In contrast, SrHf-Nd isotopes will reflect mostly "enriched" components. There is no good reason to expect Os isotopes to correlate with isotope systems where the daughter isotope is an incompatible element and in fact few magma suites shown good correlation between these different isotopic systems.

Focusing on the low $\Delta \varepsilon \mathrm{Hf}$ kimberlites, these values are very difficult to generate by infiltration and relative short maturation (10's Myr) of an asthenospherederived melt within lithospheric mantle. Depleted lithospheric mantle cannot be the sole source of such signatures because such rocks have ultra-low Hf and $\mathrm{Nd}$ levels and almost all have very radiogenic $\mathrm{Hf}$ isotopes. Even lithospheric mantle enriched in pyroxene and garnet tends to have radiogenic $\mathrm{Hf}$, or has combined Hf-Nd signatures which sit very close to the mantle array.

One possible model to explain the low $\Delta \varepsilon H f$ values is that melts derived from the asthenospheric mantle interact with metasomatic veins such as MARIDs. Only interaction with ancient MARID veins is capable of generating low $\Delta \varepsilon \mathrm{Hf}$ signatures and this has been appealed to in order to explain the Hf-Nd characteristics of lamproites (Nowell et al. this volume). All MARID veins in the $S$. African lithosphere are relatively young $(<200 \mathrm{Myr})$, possibly due to their low solidi making them vulnerable to plume heating events. Such young MARID assemblages will not have the extreme Hf-Nd isotope variation required. In addition, more ancient MARID veins would evolve to very radiogenic $\mathrm{Sr}$ isotope compositions that would influence the tight Group I kimberlite range. MARID assemblages have not been reported in the Slave lithospheric mantle and yet LDG kimberlites show the low $\Delta \varepsilon H f$ signatures seen in Kaapvaal kimberlites (Fig. 1). Lastly, REE modelling and the high Cr-Ni contents of kimberlitic melts lead le Roex et al. (2003) to conclude that MARIDs are not likely to be significant source components for Group I kimberlites. Even if such metasomatic veins do become ingested by kimberlite, this still leaves the issue of the original source of the kimberlitic magma. Nowell et al. (2004) preferred to explain the Hf-Nd isotope 
systematics of Group I kimberlites and their megacrysts via a melting of ancient recycled oceanic crust. Such an origin has also been invoked to explain the similar, but less extreme low $\Delta \varepsilon H f$ values observed in HIMU basalts (Elliott et al., 2007) which cannot be influenced by any MARID component. While such an origin may explain the $\mathrm{Nd}-\mathrm{Hf}-\mathrm{Sr}$ isotope characteristics, oceanic crust cannot be the only source component because Os isotopes and concentrations would be far too high and too low respectively and other compatible elements would be far too depleted.

The relatively unradiogenic Os isotope compositions and high Os contents of most Group I kimberlites clearly indicate that they originate from olivine-rich peridotitic sources and that Os isotopes are dominated by such sources. There is some overlap between the low ${ }^{187} \mathrm{Os} /{ }^{188}$ Os kimberlites and cratonic peridotites from southern Africa (Fig. 2) although very few cratonic peridotites have Os isotope compositions close to the more abundant, higher ${ }^{187} \mathrm{Os} /{ }^{188}$ Os values $(0.127$ to 0.135 ; Fig. 2). The low ${ }^{187} \mathrm{Os} /{ }^{188}$ Os values could be derived from ancient lithospheric roots and it is clear that the peridotites comprising these roots become entrained and digested in kimberlite (e.g., le Roex et al., 2003). However, the lack of clear mixing trends to the typically very low ${ }^{187} \mathrm{Os} /{ }^{188}$ Os values of cratonic peridotites suggests that not all the unradiogenic Os signatures come from the continental lithosphere. Kjarsgaard et al. (this volume) have pointed out that the best fit of any experimentally produced liquids to estimates of primary kimberlite magmas is for melting of depleted harzburgite at pressures in excess of 10 GPa. Kimberlitic melt originating from depleted harzburgite in the transition zone would be Os-rich and would display Os isotope ratios spanning the range observed in kimberlites, especially if some melt is derived via interaction with ancient recycled crust. That the convecting mantle itself has sufficient Os isotope heterogeneity to explain kimberlite Os isotope compositions is shown by the large range in abyssal peridotite ${ }^{187} \mathrm{Os} /{ }^{188} \mathrm{Os}$ values (Fig. 2). If kimberlites are derived from depleted harzburgite stored in the transition zone then they would preferentially sample some of the more depleted ${ }^{187} \mathrm{Os} /{ }^{188}$ Os values that are now commonly observed in the convecting mantle (Pearson et al., 2007). These depleted components are largely devoid of incompatible elements. Hence, melting of such depleted peridotite and interaction with associated recycled oceanic lithosphere also foundered in the transition zone, in the way proposed by Ringwood et al., (1992) is sufficient to explain the major element composition of kimberlite melts and their Hf-Nd-Sr and Os isotope systematics.

Other constraints on source location come from the presence of ultra-high pressure inclusions in some diamonds carried by Group I kimberlites including those from S. Africa and LDG. Diamonds containing these deeply derived inclusions have not been reported from either Group II kimberlites or lamproites and seem to provide strong independent evidence of an ultra-deep source for Group I kimberlites.

\section{References:}

Becker, M. and le Roex, A., 2006. Geochemistry of South African on- and off-craton Group I and group II kimberlites: Petrogenesis and source region evolution. Journal of Petrology, 47, 673-703.

Carlson, R.W., Pearson, D.G. and James, D.E.. 2005. Vein-plus-wall-rock melting mechanisms in the lithosphere and the origin of potassic alkaline magmas. Lithos. 28, 435453

Elliott, T.R., Blichert-Toft, J, Heumann, A. Koetsier, G. and Forjaz, V. 2007. The origin of enriched mantle beneath Sa o Miguel, Azores. Geochimica Acta Cosmochimica. 71, 219-240.

Kjarsgaard, B.A., Pearson, D.G., Tappe, S., Nowell, G.M. and Dowall, D.P. 2008. Kimberlites: High $\mathrm{H}_{2} \mathrm{O} / \mathrm{CO}_{2}$, MgO-rich , Al- and K-poor silica undersaturated magmas. 9th International Kimberlite Conference, Extended abstracts.

Klein-BenDavid O., Pearson D. G., Cantigny P., and Nowell G. M. 2008. Origins of diamond forming fluids constraints from a coupled Sr-Nd isotope and trace element approach. 9th International Kimberlite Conference, Extended abstracts, 9IKC-A-00379.

le Roex, A., Bell, D.R. and Davis, P. 2003. Petrogenesis of Group I kimberlites from Kimberley, South Africa: evidence from bulk rock chemistry. Journal of Petrology, 44, 22612286.

Malarkey, J., Pearson, D. G., Nowell, G. M., Davidson, J. P., Ottley, C. J., Mitchell, R. H., Kopylova, M., Kjarsgaard, B. 2008. Constraining the crust and mantle contributions to kimberlite: a multi-phase micro-sampling approach. This volume.

Mitchell, R.H. 2004.. Experimental studies at 5-12 GPa of the Ondermatjie kimberlite. Lithos 76, 551-564.

Nowell, G. M., Pearson, D. G., Bell, D.R, Carlson, R.W., Smith, C. B., Kempton, P. D. and Noble, S. R. 2004. Hf isotope systematics of kimberlites and their megacrysts: New constraints on their source regions. J. Petrology, 45, 1583-1612.

Nowell, G. M., Pearson, D. G., and Irving, A.J. (2008) Lu$\mathrm{Hf}$ and Re-Os isotopic studies of lamproite genesis. This volume

Paton, C. Hergt, J.M., Phillips, D., Woodhead, J.D. and Shee, S.R. 2007. New insights into the genesis of Indian kimberlites from the Dharwar Craton via in situ Sr isotope analysis of groundmass perovskites. Geology, 35, 1011-1014

Pearson, D.G. and Wittig, N.. in press. Formation of Archaean continental lithosphere and its diamonds: the root of the problem. Journal of the Geological Society, London. 165, 1-20.

Pearson, D.G., Parman, S.W. and Nowell, G.M. 2007. A link between large mantle melting events and continent growth seen in Osmium isotopes. Nature, 449, 202-205.

Ringwood, A.E., Kesson, S.E., Hibberson, $W$ and Ware, N. 1992. origin of kimberlites and related magmas. 113, 521538.

Schrauder M. and Navon O. 1994. Hydrous and carbonatitic mantle fluids in fibrous diamonds from Jwaneng, Botswana. Geochimica et Cosmochimica Acta 58, 761-771. 